\title{
IAMJ
}

INTERNATIONAL

AYURVEDIC

MEDICAL JOURNAL

\section{STUDY OF PURUSH SIDDHANT WITH SCIENTIFIC APPROACH}

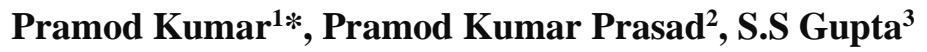 \\ ${ }^{1}$ P. G (Scholar) Rachana Sharir, Govt. Ayurvedic College, Patna, India \\ ${ }^{2}$ P.G (Scholar) Rachana Sharir, Govt. Ayurvedic College, Patna, Bihar, India \\ ${ }^{3}$ (Prof) S.S Gupta, H.O.D OF Rachana Sharir Dept. Govt. Ayurvedic College, Patna, India
}

Corresponding Author: drpramodrai8@gmail.com

\section{https://doi.org/10.46607/iamj3109112021}

(Published Online: November 2021)

Open Access

(C) International Ayurvedic Medical Journal, India

Article Received: 26/10//2021 - Peer Reviewed: 07/11/2021 - Accepted for Publication: 08/11/2021

\section{Check for updates}

\begin{abstract}
The word "Purush" in its most social sense means man but in the aspect of Ayurveda, the term purush is represented as atma or chetana dhatu (chetana-life and dhatu-element). The concept of the existence of atman (soul) is generally not accepted by modern science. According to Indian philosophy, the ultimate truth or absolute soul is one and he is Chetana (Sarvam Khalu Idam Brahm). Treatment of Panchmahabhut Sharir with presence of purush is known as Chikitsya Purush. Purush is supreme soul, pure conscious, unchanging, immortal neither birth nor death. It is essential for the creation of the universe and the living world. In the presence of purush gains knowledge through the mind. All the actions through karmendriyas, desire, pleasure, pain, life and death are performed. The purush (Kshetrajy) is lord of the house (Kshetra). The role of Purush in Srusti is laya \& parlay which is the same as catalyst's work in a reversible reaction.
\end{abstract}

Keywords: Purush, Types, Karma Chikitsa, Chaturvinshatika, Rashi, Punarjanma

\section{INTRODUCTION}

"Pure shete iti purusha" One who lives or resides in the human body is known purusha (Soul). ${ }^{1}$ Purush in its purest state or independent of prakrit exists as pure consciousness, inactive, uncreated, unchanging, and 
indestructible. Purush operates in the background to control \& co-ordination of evolution and the world of a living being. According to charak, all experiences felt by a human being in the world are due to the presence of chetana or purush. Purush is a complex concept and in charak samhita the world purush denotes the following meanings-atma, chetana, purushe, murtimanto, rashipurush, person etc. Sankhya philosophy teaches that the prakriti and Purusha are the basic elements of the universe. Prakriti refers to basic cosmic material that is the root of all beings and purusha is cetana (conscious energy) that governs life.For example, a lame person is unable to walk on the other hand a blind man is unable to see but they both assemble to be able to go anywhere by being guided by each other. ${ }^{2}$ Some scholars believed paranirmanavada (follower of divine theory) that origin of the universe by the union of prakrti - purush is decided by para(god)'wish. The basic elements accepted by sankyayoga is Prakriti and purush. According to vaisheshik, nyay and mimansa darsan the three basic elements are iswar, jivatma and prakti. According to acharya charak purush lakshanas-inspiration \& expiration, blinking of the eyes, life, mental perceptions, coordination between the organs, memory movements in dreams, the anticipation of death, co-ordination between the eyes, desires, enmity, pleasure, pain, effort, consciousness, wisdom (buddhi), memory and ego are characteristics of purush. All these are the sign of a living being. These signs are not seen in a dead body. So, these are considered to be proof of the existence of the soul. ${ }^{3}$ Purush is the only witness /sakshi of all activities of the body during the whole life of a human being. satva (mind), atma (purush)and sharir(body)are just as the legs of the tripod of life. The existence of purush realizes on the action of the world than lesser non-materialistic visibility. The soul is a two-fold-the supreme soul (paramatma) and the individual soul is different in each body known jivatma. the special quality of atma is satva guna. When leaving the manas (mind) and sharir becomes an individual soul. Charak mentions that the paramatma is the witness of all activities of the universe as he is an observer of all activities. Acharya charak mentions that the paramatma is neither created nor destructed ${ }^{4}$. Several atmas (jivatmas) according to sankhaya is considered to be innumerable. Everybody will have a separate atma. The following reasons substantiate the statement that atmas are innumerable. (1) Atma in all the beings is only one then there should be no difference in their experience of pleasure and pain. But each atma is having its own experience. (2) every atma has its cycles of birth and death. These points support the existence of the multiplicity of atma. Types (1) Samyoga purush- samyoga mean union as purush is the union of different factors (tattvas). Vedanta and Mimansa talk about Veda's way about Brahma. Ekdhatuja Purush is explained about the same i.e., Atma. ${ }^{5}$ (2) Dwaidhatuja purushpurush is the union of two factors kshetra(body) and kshetrajna (soul). (3) Tridhatuja purush-according to charak mind, soul and body these three make a tripod on which the living world stands. (4) Shad dhatuja purush-the union of five mahabhut and atma or soul. (5) Chaturvimshati tattvatmaka purush- as purush is considered to be the union of 24 factors, it is called chaturvimshati, tattvatmak, purush-prakti, ahamkara(ego), mahat(intellect), manas, five tanmatras, five mahabhut, five jnnendriyas and five karmendriyas. ${ }^{6}$ (6) Panchavinshati tattvatmaka purush- union of above mentioned 24 factors and chetana or atma is the $25^{\text {th }}$ factor. (7) Karma purusha is also known as chikitsya or rashi purush-the body will experience pain, pleasure, and also suffers from disease when associated with atma. Since treatment and preventive medicine are performed only the atma is associated with the body. (8) Sukshma purush- that is not visible to eyes. (9) Ativahika purush-the word ativahik mean migration, Sukshma sharir migrating from one body to the other. If it is accepted that atma and mana are the same, the indriyas should perceive the knowledge of the objects in the state of nidras also. Indriyas cannot perceive knowledge while sleeping. According to the Vaisheshika Darshana mention that the minds and souls are eternal in existence and infinite in number and souls are pluralistic, ubiquitous, and minds are atomic. The mind is the linking factor between the soul and the organs of the senses. Soul associated 
mind which acts as its instrument of knowledge, feeling and action. ${ }^{7}$ Manas (Mind) has been conceived to be a functional element of ATMAN (soul) which is described in Vedas - the earliest written script of the human race. ${ }^{8}$ Manas is the cause of the disease. Jnana (Knowledge), Buddhi (Intelligence), Smriti (Memory) are the outcome of mental activity. Manas is conjugated with Atma and moves from one body to another and leads to Punarjanma. ${ }^{9}$ According to Astik darshanas, in those human beings punarjanma occurred who are not free from manasik dosh raja and tama.$^{10}$ Acharya Charak defined punarjanma as When the body is destroyed atma takes shelter in another physical body. This process of departure of the old body and entrance into the new body depends upon the karma-phala of the jivatma ${ }^{11}$. As a human being leaves the old clothes and wears new clothes such similar to atma also leaves the old bhowtika sarir as known as the birth body and leaves the sarir is called death. In Geeta Krishna says that atma cannot be destroyed by any weapon, air, water, or heat .it doesn't take birth \& doesn't go to death. ${ }^{12}$ Soul Parimana and Lakshana Size of the soul varies with the size of the body. Charaka mentions that Soul is Vibhu and Mohan in Parimana. Ramanuja and Vedantins say Anu Pramana. Jains mention Madhyama Pranama. Nyaya and Vaisheshikas mention mahat Pranama. ${ }^{13}$ According to Vishnu puran atma is one but it exists in five forms are as bhutatma, indriyatma, pradhanatma, jivatma and pramatma. According to vedant philosophy atma is part of the supreme and like bubbles in the water, the worlds rise, exist and dissolve in the supreme self. Sankya darsan sate that purush is trigunatit, viveki, chetan, vibhu and aprsavdharmi. Acharya Sushrut accepted atma as nity and anu form. According to yogadarsana iswar is a particular purush that is untouched by the affection of life, action, and their results while impression produced by this action. In Prasnoupnishad pranshakti or pranachetana is also root of parmatma. according to katoupanishad chetana is ultimate the form of brahm (God) that belong to every living being. In Vedic science described the god-param purush also a virat purush is the source of all creation.

\section{DISCUSSION}

Purush is the form of energy that exists in-universe as to Brahman (God). In-universe energy is always constant /conserved it is not created nor destroyed.it only transforms in a different form. Atma (soul) is a conscious form of energy that can combine panchmahabhut elements in different ratios to form a visible body \& represent their existence in various actions \& stimuli by the body. Nothing is permanent in the universe. Everything (Maya) is destructible (Nashwar). Maya is a manifestation of Brahman (Supreme Soul). According to Albert Einstein $\left(\mathrm{E}=\mathrm{mc}^{2}\right.$, Material and energy form go back and forth into each other. Material (as compared to Maya) is the manifestation of energy and is destructible.

\section{CONCLUSION}

Purush or chetana (atman) is a central idea in all of the Hinduism literature as Vedas, Upanishads, Geeta, also ayurvedic samhitas. Atman is the spiritual essence in all creatures and also a human being. In Upanishad atman is a part of Brahman. The Hindu philosophy's goal in human life is to reunite the atman with the Brahman (parmatma). purush depicted a lord of the universe.

\section{REFERENCES}

1. Sushruta samhita volume-1 author Kaviraj Ambikadutta Shastri, Chaukhambha Sanskrit Sansthan Edition 2018, page-9

2. Padartha vijnana Author Prof (Dr) yogesh Chandra mishra, chaukhambha Sanskrit sansthan, edition:2007, page-33.

3. Charak Samhita Vol-\|, author-R. K Sharma \& Bhagwan Das, Chowkhamba Sanskrit seris office, edition:2012, page-329

4. Padartha vignana author Dr K.V.L Narasimhacharyule, Chowkhamba krishnadas academy, edition:2010, page-78

5. Padarth Vigyan, author Dr. B.K. Dwivedi, published by Chaukhambha Krishnadas Academy, Varanasi, Edition -2016, page-198

6. Charaka Samhita Volume-I, author Prof. P.V. Sharma Edited and published by Chaukhambha Orientalia, Varanasi, Edition 2007, page. 403 
7. World Journal of Pharmaceutical Research SJIF Impact Factor 7.523 Volume 6, Issue 2, 1273-1280. Review Article ISSN 2277- 7105, A REVIEW STUDY ON THE CONCEPT OF MANOVAHA SROTAS IN AYURVEDA AND ITS CLINICAL IMPORTANCE.

8. https://www.ncbi.nlm.nih.gov/pmc/articles/PMC37057 $01 /$

9. Kamath and Patel. UJMDS 2018, 06 (02): Page 23-25 Unique Journal of Medical and Dental Sciences 06 (02), April-June 201823 Unique Journal of Medical and Dental Sciences Available online: www.ujconline.net Review Article ISSN 2347-5579,

10. Charak samhita, (Chakrapani tika), Vd. Harishchandra singh Kushvahya, Chaukhambha orientaliya, Varanasi Sutrasthan ch. 11, sutra 27

11. Padarth vigyan author Gayatri devi, Chaukhambha Sanskrit pratishthan, edition:2007, page-186.

12. hinduwebsite.com Descriptions of Soul or Atman in The Bhagavadgita 5.www.iamj.in IAMJ: Volume 1; Issue 2; Utility of lok purush samya siddhant 5 March - April 201

13. Journal of Biological Engineering Research and Review, 2019; 6(1): 37-43 ISSN: 2349-3232 Available online at www. biologicalengineering.in/Archive

\section{Source of Support: Nil}

\section{Conflict of Interest: None Declared}

How to cite this URL: Pramod Kumar et al: Study Of Purush Siddhant With Scientific Approach. International Ayurvedic Medical Journal \{online\} 2021 \{cited November 2021\} Available from: http://www.iamj.in/posts/images/upload/2840_2843.pdf 